\title{
Static and Dynamic Balance Learning in Primary School Students
}

\author{
Anggi Setia Lengkana, ${ }^{1, *}$, Aam Ali Rahman ${ }^{1}$, Muhammad Nur Alif ${ }^{1}$, Gumilar Mulya ${ }^{2}$, Ari Priana ${ }^{2}$, \\ Dadang Budi Hermawan ${ }^{3}$ \\ ${ }^{1}$ Physical Education of Elementary Teacher Program, Universitas Pendidikan Indonesia, Bandung, Indonesia \\ ${ }^{2}$ Physical Education Program, Universitas Siliwangi, Tasikmalaya, Indonesia \\ ${ }^{3}$ Physical Education Program, Sekolah Tinggi Keguruan dan Ilmu Pendidikan Sebelas April Sumedang, Sumedang, Indonesia
}

Received October 19, 2020; Revised November 30, 2020; Accepted December 20, 2020

\section{Cite This Paper in the following Citation Styles}

(a): [1] Anggi Setia Lengkana, Aam Ali Rahman, Muhammad Nur Alif, Gumilar Mulya, Ari Priana, Dadang Budi Hermawan, "Static and Dynamic Balance Learning in Primary School Students," International Journal of Human Movement and Sports Sciences, Vol. 8, No. 6, pp. 469 - 476, 2020. DOI: 10.13189/saj.2020.080620.

(b): Anggi Setia Lengkana, Aam Ali Rahman, Muhammad Nur Alif, Gumilar Mulya, Ari Priana, Dadang Budi Hermawan (2020). Static and Dynamic Balance Learning in Primary School Students. International Journal of Human Movement and Sports Sciences, 8(6), 469 - 476. DOI: 10.13189/saj.2020.080620.

Copyright $\odot 2020$ by authors, all rights reserved. Authors agree that this article remains permanently open access under the terms of the Creative Commons Attribution License 4.0 International License

\begin{abstract}
Balance is the ability to react to any change in body position so that the body remains stable and in control. A right balance will enable a person to carry out activities and movements effectively and efficiently with minimal risk of falling. A balanced training program is given as many athletes get injured during peak periods and training for patients with Multiple Sclerosis and Down Syndrome. The author is interested in proving and implementing various forms of balance training applied to children who participate in various sports at primary school age to prevent them from avoiding injury. Therefore, all physical conditions must be met so that they are ready to receive training at the next stage. This study aims to determine the effect of learning static and dynamic balance in elementary school students. The method used is a pretest-posttest control group design experimental random sampling method. The sample is elementary school students in grades 5 and 6 . The instruments used in the form of tests are the standing crane test and the Star Balance Excursion Balance Test (SEBT). The results showed that static and dynamic balance learning significantly influenced the improvement of balance in elementary school students. In conclusion, learning static and dynamic balance together provides increased balance in elementary school students
\end{abstract}

Keywords Static and Dynamic, Balance Learning, Primary School Students

\section{Introduction}

Education is a process of human development that lasts a lifetime [1]. Education is considered a lifelong process that includes all experiences children receive at school or home, in the environment, and society through interactions with various kinds and activities. Children are not 'little adults' [2]; their bodies and mentalities differ quantitatively and qualitatively from adults. Therefore, they should be considered not only smaller but also different. Effective training programs for children must consider each age range's psychophysical characteristics to focus and take advantage of age-specific motor learning ability levels at the maximum level.

Physical education taught in schools has an essential role in providing opportunities for students to be directly involved in various learning experiences through systematic physical activities, sports, and health. This learning experience promotes better physical growth and psychological development while establishing a healthy and fit lifestyle throughout life. Physical education is education through physical activities to develop the child's total personality and the fulfillment and perfection of body, mind, and spirit [3]. Thus, Physical Education provides a learning experience to foster better physical conditions and 
psychological development and form a lifelong healthy and fit lifestyle.

There are ten components to physical condition: endurance, muscle strength, speed, flexibility, balance, coordination, agility, accuracy, and reaction [4]. All physical condition components above are vital, and good physical condition is needed to support optimal physical activity [5]. When the physical condition is good, mental health will indirectly experience positive changes [6]. The problem is that the presentation of Physical Education learning has not comprehensively supported the fulfillment of movement and good physical condition, especially in terms of moving the balance. It is because teachers in schools have not clearly and thoroughly introduced it. Moreover, during this pandemic, the interaction between teachers and students is minimal. However, it does not prevent the physical education lesson, as it was proven by reference [7].

The allocation of time is minimal for physical education in schools, so it implies a lack of vocabulary of students' movements, which results in not having balance and other physical conditions very well. When children begin to engage in achievement sports, they suffer severe injuries due to fatigue from a poor physical condition. It is a big problem for the athletes' future performance. Research has found that a person's body balance is affected by fatigue [8]. Another primary concern about the effects of fatigue on balance is in the athletic population. So far, researchers can only estimate that athletes need rest for 8-20 minutes before testing balance [8-10]. It can be a big difference depending on the situation. Therefore, after undergoing heavy training or in the final minutes of a match. Players will have a lower balance, so they fall more quickly and are prone to injury.

Through balance, the body can maintain in any position, place, and field. It can maintain the center of gravity at the fulcrum, especially in an upright position [12]. Balance is considered a key component of normal daily activities, such as walking, running, and climbing stairs. In simplest terms, equilibrium can be defined as "maintaining the body's center ability of gravity within the stability limit determined by the base support [13]. The gravity center can be defined as the point at which we can calculate the gravity torque for an object as if it were acting on. Thus, the stability limit is the sway angle that puts it out of the support base [14]. A right balance will enable a person to perform activities or movements effectively and efficiently with minimal risk of falling - two types, consisting of static balance and dynamic balance [15]. Static balance is the body's ability to maintain balance in a still position when standing on one leg or standing on a balance board [16]. Dynamic balance is the body's ability to maintain its position while moving [17]. Balance is not a finite ability but underlies our ability to perform various daily activities [18].

Furthermore, balance can develop essential skills as an essential foundation for mastering technical skills. It becomes a severe problem when body balance is not considered, and it will affect the development of other aspects of improving sports performance. Thus, it is clear that good physical condition is needed by children, one of which is balance. Children will be ready to do any movement or physical activity without fear because they have developed the foundation of their physical condition from a very young age. Children can have essential abilities because they are used in daily activities, such as walking, running, and mostly in sports and games.

By paying attention to the preceding, this study aims to improve the abilities of elementary school students in terms of static and dynamic balance, as well as to provide teachers with understanding and skills in increasing their competence in teaching the K13 program in Physical Education, which is more directed towards fulfilling basic movements for the children. With the demands of learning in the K13 program, teachers must direct the learning orientation towards a scientific approach. The purpose of the scientific approach in learning, among others, is to improve the thinking skills of students, form the ability to solve problems systematically, create learning conditions so that students feel that learning is a need, train students in suggesting ideas, improve student learning outcomes, and develop the character of students.

Previous studies on physical education learning that focused on balance have been noted. Reference [19] found that balance training positively affected speed, agility, and balance performance. Meanwhile, [20] found that balance has a very significant correlation with reaction time. However, these previous studies have not addressed the need for balance learning with a scientific approach by the 2013 Curriculum program in Indonesia, especially for children aged 11-12. The period for that age-range is limited unless added by interactive game-based learning aid [21]. Therefore, this study seeks to fill the void by incorporating static and dynamic balance learning as one of the materials underlying Physical Education to develop students' physical conditions.

\section{Theoretical Framework}

Balance is a complex integration of the somatosensory (visual, vestibular, proprioceptive) and motor (musculoskeletal, muscle, soft tissue joints) systems whose overall work is regulated by the brain to the body's internal and external responses or influences [22]. The parts of the brain that regulate include the basal ganglia, cerebellum, and association areas. [23] explained, the factors that influence balance are as follows:

1. Center of Gravity (COG). It is the main point on an object that will distribute the object's mass evenly. If this point always supports the body, then the body is in balance. A person's ability to maintain balance in 
various forms of body positions is greatly influenced by its ability to maintain the Center of Gravity (COG) to remain within the body stability limit area (stability limit).

2. Line of Gravity (LOG). The line of gravity is an imaginary line that crosses the center of gravity vertically to the earth's center. This gravity line and its center, and the fulcrum determine the degree of stability of the body.

3. The Base of Support (BOS). It is the fulcrum core connected to the support surface or the support itself.

Moreover, coordination (dexterity) abilities depend on movement control and regulatory processes, and they are significant in sports, as they allow athletes to easily control their motor movements. Also, they allow complex movements to learn rapidly, one of the significant components of coordination skills in balance [24]. Balance is essential for children because it supports their activities during sports so they can avoid sports injuries. It was done by [25]. Additionally, injuries to the knees and ankles are common in today's athletes. Athletes often suffer from jumping sports, such as volleyball, soccer, soccer, and basketball. The ankles and knees are motion joints and joints that support and balance the body, prone to injury. Data in the United States stated that the high incidence of sports injuries in both adults and children. In adults, there are 1.5 million events a year, and half are serious injuries. In children and adolescents, the rate is higher, 3-4.3 million events per year. The incidence is the same for men and women, but two times higher in contact sports than in noncontact sports. The part of the body that is most commonly injured is the knee [26].

There are two types of balance: static and dynamic. Static balance is the body's ability to maintain body balance in a still position and for a particular time, for example, when standing. Static balance is a fundamental characteristic of normal motor development. Most motor development tests include static balance measurements. Reference [27] explained that children with developmental coordination disorders often fail to perform static balance movements. There needs to be more profound attention regarding the motor development of children. One example of this movement is the Core Stability Exercise (CSE) as an essential component in providing local strength and balance to maximize activities efficiently. Core muscle activity results from integrated work before integrating one or many joints to maintain stability and movement. Core stability is defined in the athletic setting as optimal production, which can transfer and control force from the body's center to the legs by stabilizing the torso's position and movement [28].

Likewise, it is the hip to thighs central motor control to maintain the core region's stability against different postural and external forces [29]. Core stability describes the ability to control the position and movement of the midsection. Core stability is detected in the abdominal muscles connecting the pelvis, spine, and shoulders, which helps maintain posture and provides all arm and leg movements [30].

Meanwhile, dynamic balance is the body's ability to maintain balance when moving, such as walking, running, getting up from a sitting position, and agility movements. Dynamic balance is an essential component of injury prevention and rehabilitation in sports. Core muscle training has been hypothesized as an intervention to improve balance. The dynamic balance movement emphasizes several points of movement, such as moving a small box, passing a wall, parkouring a balance hurdle, throwing and catching, jumping on one leg, and lying on a Swiss ball. Balance exercises are performed on a flat surface and using special tools or facilities, such as gym balls, balance boards, vital physio jumps, balance blocks, carriages and balls, steppers, and pedestrians.

\section{Materials and Methods}

\subsection{Research Design}

The population in this study were elementary school students. The participants in this study were 23 male students and 23 female students so that the total participants were 46 students with an age range between 11 and 12 years. The number of primary schools in cluster 1 (students' qualification intake level) is around 36 schools, so the researcher took several student representatives from the 36 schools. The researcher divided the population into separate groups, and several randomly selected participants were taken. Therefore, Random Cluster Sampling was chosen. To obtain research data, the researcher divided the sample into two groups. The first group is a group that uses static balance learning. A second group is a group that uses dynamic balance learning. The participants were children who actively participate in sports, such as club football, athletics, and several other sports. The treatment was given for three months in carrying out the research. It took 2 hours for each session, and it was held three sessions in a week.

\subsection{Procedures}

The scientific approach outline steps are divided into five steps, which are used as basic assumptions or approaches in learning in the 2013 Curriculum. The five steps include: observing, questioning, gathering information/trying, reasoning or associating, and communicating. 
Table 1. Scientific Steps in Physical Education Lesson Plan

\begin{tabular}{|c|c|}
\hline \multicolumn{2}{|r|}{ SESSION } \\
\hline ACTIVITIES & DESCRIPTION \\
\hline Opening & $\begin{array}{l}\text { 1. Greeting students. } \\
\text { 2. Asking one of the students to lead the prayer before starting the lesson. } \\
\text { 3. } \\
\text { 4. } \\
\text { Asking questions related to the material to be studied to determine how far the students' initial competence on } \\
\text { 5. } \\
\text { 6. De material to be studied. } \\
\text { 7. Motivating students to keep learning and exercising around the place of residence. }\end{array}$ \\
\hline Core & 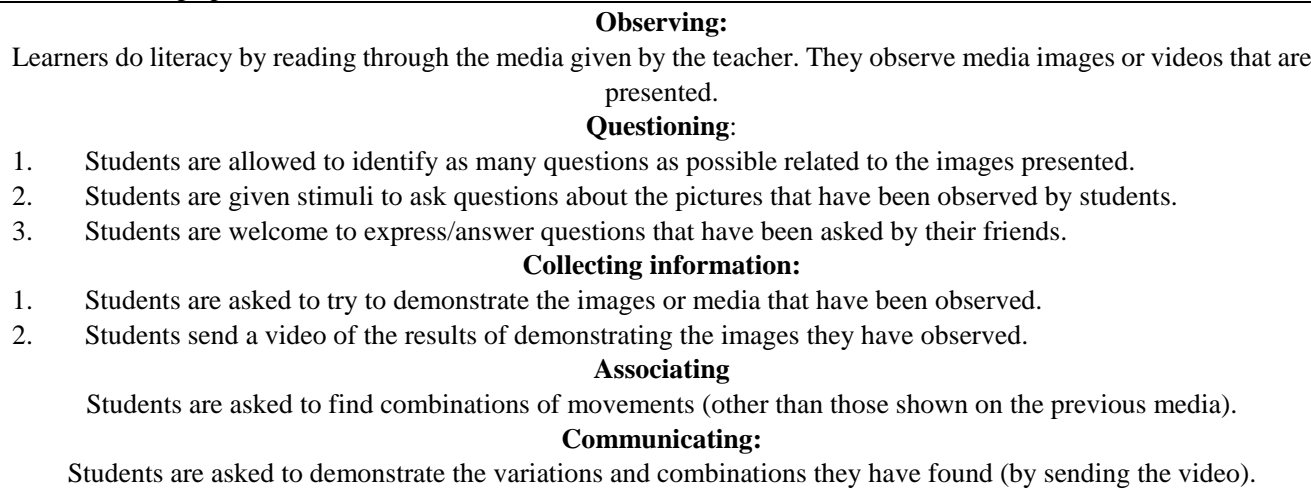 \\
\hline Closing & $\begin{array}{ll}\text { 1. } & \text { Cooling down activities around the place where he lives. } \\
\text { 2. } & \text { Making reflections on the material. } \\
\text { 3. } & \text { Making conclusions from the entire learning process. } \\
\text { 4. } & \text { Delivering the next meeting plan. } \\
\text { 5. } & \text { Giving assignments to students. } \\
\text { 6. } & \text { Closing the teaching and learning activities. }\end{array}$ \\
\hline
\end{tabular}

The steps in Table 1 are used as a reference for the author in developing a balance learning design using a scientific approach in the 2013 curriculum. As discussed in the lesson plan, Physical Education learning prepares learners to be physically fit, but it must also consider the attitude and value [31].

Group A was given a static balance learning treatment, with Core Stability Exercise (CSE). At the beginning of learning static balance, the reps were used three times, but the movement duration was 10-20 seconds for each. However, the days add up to 30-35 seconds per movement, according to the principle of overloading. At the same time, group B was given the treatment by learning dynamic balance, with materials such as standing on a balance board, balance obstacle parkour, standing on a trampoline with only one foot on the surface. To make this even more challenging, get the other person to walk on the trampoline (or jump) while balancing. Each movement can be done 10-15 times per motion. The tools used in this balance study are mats, cones, field tennis balls, balance boxes, modified ladders.

\subsection{Research Instrument}

Data was collected using tests. The researchers used the Standing Stork Test [32] as a preliminary test and a final test to describe the static balance ability. For Standing Stork Test, in principle, the longest time in maintaining a balanced position is the time used to assess participants' balance. The following can be seen in Table 2 below, which is the norm for evaluating static balance using a standing stork test.

Table 2. Norms of Static Balance, Standing Stork Test

\begin{tabular}{|c|c|c|c|}
\hline No & Male & Category & Female \\
\hline 1 & $51 \mathrm{sec}-$ over & Very Good & $28 \mathrm{sec}-$ over \\
\hline 2 & $37 \mathrm{sec}-50 \mathrm{sec}$ & Good & $23 \mathrm{sec}-27 \mathrm{sec}$ \\
\hline
\end{tabular}

Further, to describe the ability of dynamic balance, the researchers used the Star Balance Excursion Balance Test (SEBT) [33].

Before the SEBT was conducted, a small number of settings were applied. Four strips of athletic tape were needed, and each had 6-8 feet of length. Two strips were used to form a plus '+' sign, and the other two were placed above it to form an ' $x$ ' so that a star shape was formed. The lines must have an angle of $45^{\circ}$ [30]. SEBT aims to maintain one leg's position while reaching as far as possible with the contralateral leg [34].

The samples have to balance 8 directions for one leg while using the other to step as far as possible. The eight directions are anterior, anteromedial, medial, posteromedial, posterior, posterolateral, lateral, and anterolateral [35]. Anterior, posteromedial, and posterolateral directions appeared to be essential to identify individuals' chronic ankle instability and greater 
risk of lower limb injuries suffered by athletes [36].

When the test finished, and all performances were measured and recorded, the test administrator calculated the athlete's SEBT performance scores using the following simple equations: Average distance in each direction $(\mathrm{cm})$ $=$ Reach $1+$ Reach $2+$ Reach 3/3, Relative (normalized) distance in each direction (\%) = Average distance in each direction/leg length $\mathrm{x} 100$. These calculations are for both legs in each direction. It provides a total of 16 scores per athlete [37].
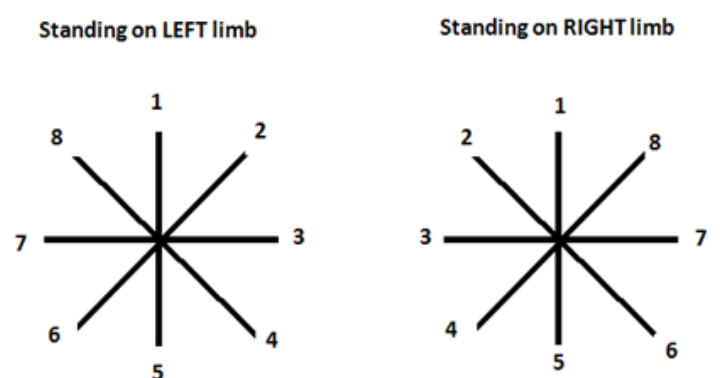

\footnotetext{
1. Anterior

2. Anteromedial

3. Medial

4. Posteromedial

5. Posterior

6. Posterolateral

7. Lateral

8. Anterolateral
}

Figure 1. Star Balance Excursion Balance Test (SEBT)

\section{Result and Discussion}

Table 3. The distribution of initial score and the final score of the standing stork test on the respondents

\begin{tabular}{|c|c|c|c|}
\hline No & Characteristics & Right Leg & Left Leg \\
\hline 1 & $\begin{array}{c}\text { Initial Score of Standing } \\
\text { Stork Test }\end{array}$ & & \\
\hline \multirow{5}{*}{2} & Mean & 10.08 & 9.31 \\
\hline & SD & 5.00 & 4.71 \\
\hline & $\begin{array}{c}\text { Final Score of Standing } \\
\text { Stork Test }\end{array}$ & & \\
\hline & Mean & 13.34 & 12.28 \\
\hline & SD & 1.25 & 1.72 \\
\hline
\end{tabular}

Table 3 presents that the standing stork test mean score for the right leg before the test was 10.08 with the Deviation Standard of 5.00, and it changed to 13.34 after conducting the test with Standar of Deviation in 1.25. Meanwhile, the mean score for the left leg before the test was 9.31 with an SD of 4.71, and 12.28 after conducting the test with an SD was 1.72. Balance changes were measured using the standing stork test, in which the results were continuum data.

Table 4 presents that the mean score on the Star Balance Excursion Balance Test (SEBT) of the right leg before the test was 10.56, with an SD of 6.34, and the mean score after the test was 14.47, the SD was 2.12. Meanwhile, the mean score on the Star Balance Excursion Balance Test (SEBT) of the left leg before conducting the test was 9.68, with an SD of 5.76, and after conducting the test, the mean score was 12.87 with an SD was 3.24. Balance changes were measured using the Star Balance Excursion Balance Test (SEBT), in which the results were continuum data.

Table 4. The distribution of initial score and the final score of the Star Balance Excursion Balance Test (SEBT) on the respondents

\begin{tabular}{cccc}
\hline No & Characteristics & Right Limb & Left Limb \\
\hline 1 & Initial Score of (SEBT) & & \\
& Mean & 10.56 & 9.68 \\
& SD & 6.34 & 5.76 \\
& Final Score of (SEBT) & & \\
& Mean & 14.47 & 12.87 \\
& SD & 2.12 & 3.24 \\
\hline
\end{tabular}

\subsection{Results of Data Normality Test}

The data normality test used in this research was the statistical Lilliefors test. The data from the test results was informed in Table 5 below:

Table 5. Results of Data Normality Test of the Standing Stork Test

\begin{tabular}{cccc}
\hline Test Group & $\mathrm{L}_{\text {count }}$ & $\mathrm{L}_{\text {table }}$ & Result \\
\hline Initial Test & 0.075 & 0.220 & Normal \\
Final Test & 0.185 & 0.220 & Normal \\
\hline
\end{tabular}

Table 5 above shows that $\mathrm{L}_{\text {count }}\left(\mathrm{L}_{0}\right)$ was smaller than $\mathrm{L}_{\text {table }}$ with a significant level of 0.05 , indicating that the data were normally distributed.

Table 6. Results of Data Normality Test of the Star Balance Excursion Balance Test (SEBT)

\begin{tabular}{cccc}
\hline Test Group & $\mathrm{L}_{\text {count }}$ & $\mathrm{L}_{\text {table }}$ & Result \\
\hline Initial Test & 0.069 & 0.220 & Normal \\
Final Test & 0.200 & 0.220 & Normal \\
\hline
\end{tabular}

Table 6 above shows that $\mathrm{L}_{\text {count }}\left(\mathrm{L}_{0}\right)$ was smaller than $\mathrm{L}_{\text {table }}$ with a significant level of 0.05 . It showed that the data were normally distributed.

\subsection{Results of Hypothesis Testing using t-test}

According to each test data usually distributed, hypothesis testing was conducted using a one-sample test (t-test). In this hypothesis testing, the criteria for $t$ values were determined based on the distribution table of the value of $t$. The results could be seen in Table 6 below:

Table 6. Results of Hypothesis Testing using t-test

\begin{tabular}{cccc}
\hline Group Test & $\mathrm{t}_{\text {count }}$ & $\mathrm{t}_{\text {table }}$ & Result \\
\hline Static Balance & 28.236 & 1.761 & Significant \\
\hline Dynamic Balance & 29.467 & 1.761 & Significant \\
\hline
\end{tabular}


Table 6 above shows that the value of $\mathrm{t}_{\text {count }}$ group Static balance in the significant value of 0.05 was outside the interval of $t_{\text {table }}\left(t_{\text {count }}>t_{\text {table }}=28.236>1.761\right)$. Therefore, from the data, there were significant differences in the sample group after conducting Static Balance. Moreover, the value of $t_{\text {count }}$ group Dynamic Balance in the significant value of 0.05 was outside the interval of $t_{\text {table }}$ $\left(t_{\text {count }}>t_{\text {table }}=29.467>1.761\right)$. Therefore, from the data, there were significant differences in the sample group after conducting Dynamic Balance.

Static balance is the ability to maintain the body position where the Center of Gravity (COG) does not change or to maintain two equilibriums in a fixed position. An example of a static balance is standing on one leg using a balance board [38]. An example of a static balance movement is Core Stability Exercise (CSE). According to reference [39], CSE will help maintain good posture in doing movement and become the basis for all movements in the arms and legs. It shows that with optimal posture stability, the mobility of the extremities can be achieved efficiently. CSE is a dynamic concept that kept changing in fulfilling posture adjustments and external body weight. It showed that training by simulating sports movement patterns could improve core stability [40]. The results showed that the Core Stability Exercise (CSE) significantly improved static and dynamic balance learning [41]. At the same time, dynamic balance is the ability to maintain body position, COG is always changing, or maintains equilibrium when moving on a moving foundation (dynamic standing) that will put the body into an unstable condition. An example of dynamic balance is walking or moving from one place to another using several media such as balance beam, hoppers and balls, steppers, and walkers [42]. The results show that plyometric and dynamic balance exercises can improve balance [43-45].

As physical education teachers, we must educate our students early on the definition and importance of a strong core and teach simple and effective ways to strengthen it. As always, the best thing children can do to improve their core strength is play. Good old-fashioned games include running, climbing, jumping, crawling, and exploring in an unstructured environment. However, as teachers, we must allow our students to strengthen their core stability through various exercises.

\section{Conclusions}

Based on data on the improvement results in this research, static and dynamic balance learning significantly affected primary school students' balance. It indicated an increase in the mean score and the improvement of the initial test and final test. Therefore, this research proved that static and dynamic balance learning prevents injury and improves physical conditioning in primary school students. However, to further improve this balance learning quality, it would be better if some other supporting technologies such as Android-based applications on smartphones attract more interest and make it easier for children to learn balance movements at home. This balanced learning is beneficial and should be of concern for teachers in schools when teaching physical education. The benefits of learning the balance movement will be felt at that time and in the future.

\section{Acknowledgments}

The authors send the grateful thanks for all participants in this study and also the headmasters of the school where the study was conducted.

\section{REFERENCES}

[1] B. E. Course, Basics in Education. New Delhi: Publication Divsion by the Secretary, National Council of Educational Research and Training, Sri Aurobindo Marg, New Delhi 110 016 and printed at Karan Press (A Unit of KBT Plastics Pvt. Ltd.) A-215, Sector-83, Noida U.P., 2014.

[2] A. S. Lengkana, J. Tangkudung, and A. Asmawi, "The effectiveness of thigh lift exercises using rubber on the ability of acceleration on sprint runs," in Journal of Physics: Conference Series, 2019, vol. 1318, no. 1, p. 12031. doi:10.1088/1742-6596/1318/1/012031

[3] E. Flavier, S. Bertone, D. Hauw, and M. Durand, "The meaning and organization of physical education teachers' actions during conflict with students,” J. Teach. Phys. Educ., vol. 22, no. 1, pp. 20-38, 2002. doi: 10.1123/jtpe.22.1.20

[4] T. O. Bompa and C. Buzzichelli, Periodization-: theory and methodology of training. Human Kinetics, 2018.

[5] R. K. Shayne, V. A. Fogel, R. G. Miltenberger, and S. Koehler, "the Effects of Exergaming on Physical Activity in a Third-Grade Physical Education Class,” J. Appl. Behav. Anal., vol. 45, no. 1, pp. 211-215, 2012. doi: 10.1901/jaba.2012.45-211

[6] L. Røset, K. Green, and M. Thurston, "Norwegian youngsters' perceptions of physical education: exploring the implications for mental health,” Sport. Educ. Soc., vol. 25, no. 6, pp. 618-630, 2020. doi: 10.1080/13573322.2019.163 4043

[7] A. Rahman, A. Suherman, D. Susilawati, and G. P. Putra, "RADEC (reading, answering, demonstrating, explaining, and creating) in lms to teach tennis without field practicing," Universal Journal of Educational Research, vol. 8, no. 11, pp. 5433-5442, 2020. doi: 10.13189/ujer.2020.081146

[8] M. A. Garcia-Luna, J. M. Cortell-Tormo, J. González-Martinez, M. Garcia-Jaén, and others, "The Effects of Tissue Flossing on Perceived Knee Pain and Jump Performance: A Pilot Study,” International Journal of Human Movement and Sports Sciences, Vol. 8, No. 2, pp. 


\section{3 - 68,2020. doi:10.13189/saj.2020.080203}

[9] K. M. Means, D. E. Rodell, and P. S. O’sullivan, "Balance, mobility, and falls among community-dwelling elderly persons: effects of a rehabilitation exercise program," Am. $J$. Phys. Med. Rehabil., vol. 84, no. 4, pp. 238-250, 2005. doi: 10.1097/01.PHM.0000151944.22116.5A

[10] P. K. Yim-Chiplis and L. A. Talbot, "Defining and measuring balance in adults,” Biol. Res. Nurs., vol. 1, no. 4, pp. 321-331, 2000. doi: 10.1177/109980040000100408

[11] Z. G. Fox, J. P. Mihalik, J. T. Blackburn, C. L. Battaglini, and K. M. Guskiewicz, "Return of postural control to baseline after anaerobic and aerobic exercise protocols," $J$. Athl. Train., vol. 43, no. 5, pp. 456-463, 2008. doi: 10.4085/1062-6050-43.5.456

[12] E. E. Alper Kartal, "Investigation of the Effect of 6-week Yoga Exercises on Balance, Flexibility, and Strength in Soccer Players," International Journal of Human Movement and Sports Sciences, vol. Vol. 8, no. No.3, pp. 91-96, 2020. doi: 10.13189/saj.2020.080303

[13] N. Shkuratova, M. E. Morris, and F. Huxham, "Effects of age on balance control during walking," Arch. Phys. Med. Rehabil., vol. 85, no. 4, pp. 582-588, 2004. doi: 10.1016/j.apmr.2003.06.021

[14] G. Batson, "Update on proprioception: considerations for dance education,” J. Danc. Med. Sci., vol. 13, no. 2, pp. 3541, 2009.

[15] B. C. Conner et al., "The cross-sectional relationships between age, standing static balance, and standing dynamic balance reactions in typically developing children," Gait Posture, vol. 73, pp. 20-25, 2019. doi: 10.1016/j.gaitpost.2019.07.128

[16] C. Condon and K. Cremin, "Static balance norms in children,” Physiother. Res. Int., vol. 19, no. 1, pp. 1-7, 2014. doi: 10.1002/pri.1549

[17] S. D. Jazi, F. Purrajabi, A. Movahedi, and S. Jalali, "Effect of selected balance exercises on the dynamic balance of children with visual impairments," J. Vis. Impair. Blind., vol. 106, no. 8, pp. 466-474, 2012 . doi: $10.1177 / 0145482 \times 1210600803$

[18] D. Abrahamova and F. Hlavacka, "Age-related changes of human balance during quiet stance,” Physiol. Res., vol. 57, no. 6, pp. 1-17, 2008.

[19] S. Bozkurt, O. Erkut, and O. Akkoç, "Relationships between Static and Dynamic Balance and Anticipation Time, Reaction Time in School Children at the Age of 10-12 Years.," Universal Journal of Educational Research, vol. 5, no. 6, pp. 927-931, 2017. doi: 10.13189/ujer.2017.050603

[20] H. Acar and N. Eler, "The Effect of Balance Exercises on Speed and Agility in Physical Education Lessons.," Universal Journal of Educational Research, vol. 7, no. 1, pp. 74-79, 2019. doi: 10.13189/ujer.2019.070110

[21] A. A. Rahman and A. Angraeni, "Empowering Learners with Role-Playing Game for Vocabulary Mastery,” Int. J. Learn. Teach. Educ. Res., vol. 19, no. 1, 2020. doi: 10.26803/ijlter.19.1.4

[22] L. Ricotti, "Static and dynamic balance in young athletes," J. Hum. Sport Exerc., vol. 6, no. 4, pp. 616-628, 2011. doi: 10.4100/jhse.2011.64.05

[23] J. Gilchrist et al., "A randomized controlled trial to prevent noncontact anterior cruciate ligament injury in female collegiate soccer players,” Am. J. Sports Med., vol. 36, no. 8, pp. 1476-1483, 2008. doi: 10.1177/0363546508318188

[24] M. Rahimi, F. Halabchi, G. H. GHasemi, and V. Zolaktaf, "Prevalence of karate Injuries in Professional Karateka in Isfahan,” Ann. Mil. Heal. Sci. Res., vol. 3, no. 7, pp. 201-207, 2009.

[25] R. H. Geuze, "Static balance and developmental coordination disorder," Hum. Mov. Sci., vol. 22, no. 4-5, pp. 527-548, 2003. doi: 10.1016/j.humov.2003.09.008

[26] W. Ben Kibler, J. Press, and A. Sciascia, "The role of core stability in athletic function.,” Sports Med., vol. 36, no. 3, pp. 189-198, 2006. doi: 10.2165/00007256-200636030-00001

[27] F. P. Carpes, F. B. Reinehr, and C. B. Mota, "Effects of a program for trunk strength and stability on pain, low back and pelvis kinematics, and body balance: a pilot study," $J$. Bodyw. Mov. Ther., vol. 12, no. 1, pp. 22-30, 2008. doi: 10.1016/j.jbmt.2007.05.001

[28] S. Sorosky, S. Stilp, and V. Akuthota, "Yoga and pilates in the management of low back pain," Curr. Rev. Musculoskelet. Med., vol. 1, no. 1, pp. 39-47, 2008. doi: 10.1007/s12178-007-9004-1

[29] B. Mackenzie, "Performance evaluation tests," London Electr. World plc, 2005.

[30] L. C. Olmsted, C. R. Carcia, J. Hertel, and S. J. Shultz, "Efficacy of the star excursion balance tests in detecting reach deficits in subjects with chronic ankle instability," $J$. Athl. Train., vol. 37, no. 4, p. 501, 2002. doi: 10.1002/pri.1589

[31] T. Muhtar, T. Supriyadi, A. S. Lengkana, and S. Hanifah, "Religious Characters-Based Physical Education Learning in Elementary School,” Int. J. Learn. Teach. Educ. Res., vol. 18, no. 12, 2020. doi: 10.26803/ijlter.18.12.13

[32] P. J. Plisky, P. P. Gorman, R. J. Butler, K. B. Kiesel, F. B. Underwood, and B. Elkins, "The reliability of an instrumented device for measuring components of the star excursion balance test.," N. Am. J. Sports Phys. Ther., vol. 4, no. 2, pp. 92, 2009.

[33] T. ver google books Miller, NSCA's Guide to TESTS AND ASSESSMENTS. Human Kinetics, 2012.

[34] A. Delitto, “The Link Between Balance Confidence and Falling,” Phys. Ther. Res. That Benefits You, 2003.

[35] J. M. Willardson, "Core stability training: Applications to sports conditioning programs," J. Strength Cond. Res., vol. 21, no. 3, pp. 979-985, 2007. doi: 10.1519/R-20255.1

[36] A. Dello Iacono, D. Martone, A. Alfieri, M. Ayalon, and P. Buono, "Core Stability Training Program (CSTP) effects on static and dynamic balance abilities," Gazz. Medica Ital. Arch. per le Sci. Mediche, vol. 173, no. 4, pp. 197-206, 2014.

[37] M. V Paterno, G. D. Myer, K. R. Ford, and T. E. Hewett, "Neuromuscular training improves single-limb stability in young female athletes,” J. Orthop. Sport. Phys. Ther., vol. 34, no. 6, pp. 305-316, 2004. doi: 


\subsection{9/jospt.2004.34.6.305}

[38] A. Maćków, M. Małachowska-Sobieska, E. Demczuk-Włodarczyk, M. Sidorowska, A. Szklarska, and A. Lipowicz, "Influence of Neurophysiological Hippotherapy on the Transference of the Centre of Gravity Among Children with Cerebral Palsy," Ortop. Traumatol. Rehabil., vol. 16, no. 6, pp. 581-593, 2014. doi: $10.5604 / 15093492.1135048$

[39] A. K. Akodu, S. R. A. Akinbo, and A. S. Omootunde, "Comparative effects of muscle energy technique and core stability exercise in the management of patients with non-specific chronic low back pain,” Med. Sport. J. Rom. Sport. Med. Soc., vol. 13, no. 1, p. 2860, 2017.

[40] Y. He, W. Sun, X. Zhao, M. Ma, Z. Zheng, and L. Xu, "Effects of core stability exercise for patients with neck pain: A protocol for systematic review and meta-analysis," Medicine (Baltimore)., vol. 98, no. 46, 2019. doi: 10.1097/MD.0000000000017240

[41] M. B. Shamsi, M. Rezaei, M. Zamanlou, M. Sadeghi, and M. R. Pourahmadi, "Does core stability exercise improve lumbopelvic stability (through endurance tests) more than general exercise in chronic low back pain? A quasi-randomized controlled trial," Physiother. Theory Pract., vol. 32, no. 3, pp. 171-178, 2016. doi: $10.1080 / 09593985.2016 .1185310$

[42] K. K. Sarker, J. Sethi, U. Mohanty, and others, "Comparative clinical effects of spinal manipulation, core stability exercise, and supervised exercise on pain intensity, segmental instability, and health-related quality of life among patients with chronic nonspecific low back pain: A randomized control ,” J. Nat. Sci. Biol. Med., vol. 11, no. 1, p. 27, 2020. doi: 10.4103/jnsbm.JNSBM_101_19

[43] C. Hrysomallis, "Balance ability and athletic performance," Sport. Med., vol. 41, no. 3, pp. 221-232, 2011. doi: $10.2165 / 11538560-000000000-00000$

[44] R. S. Weinberg and D. S. Gould, Foundations of sport and exercise psychology. Human Kinetics, 2018.

[45] P. Giagazoglou, D. Kokaridas, M. Sidiropoulou, A. Patsiaouras, C. Karra, and K. Neofotistou, "Effects of a trampoline exercise intervention on motor performance and balance ability of children with intellectual disabilities," Res. Dev. Disabil., vol. 34, no. 9, pp. 2701-2707, 2013. doi: 10.1016/j.ridd.2013.05.034 